\title{
Self-managing Socialism and its Space: Blok 5 and Challenging Rhetoric of Flexibility
}

\author{
Marija Bojović ${ }^{1}$ | Jelena Bajić Šestović ${ }^{2}$
}

Received: 2020-02-04 | in its final version: 2020-04-24

Abstract

The objective of this research is to highlight the importance of the cause-and-effect relationship between a society and the space it produces. Through the analysis of Blok 5 (1977), a collective residential complex in Podgorica, Montenegro, and its transformation throughout the 40-year timespan, this paper sets the ambition of disclosing one part of transition-related socio-spatial problems that Montenegrin cities are facing nowadays. The structure of this paper entails two constitutive and complementary components, i.e. a scientific-theoretical and a practical level. The theoretical part of the research is based on a systematic review of the literature dealing with the relationship between society, city and architectural space, as well as the concept of open work. Given that the research examines the socio-spatial transformations of Montenegrin cities in the context of social, economic and political change, this has been illustrated by an extract from practice - the case study of Blok 5. Since the paper relates the quality of society directly to the quality of spatial transformations over time, this research, ultimately, comes to conclusion that, in order for a society to have an affirmative stance towards its own space, that very society needs to develop an adequate system of qualitative and cultural values and needs, as well as adequate level of awareness and culture in general. Original contribution of this paper consists in pointing at the interlinkages between the European philosophical-sociological thinking and art scene of the 1960s and 1970s, and processes of design and realisation of a specific residential complex in Montenegro that was in the making in those very years, during the Yugoslav selfmanaging socialism.

Keywords: open work; production of space; dwelling culture; Podgorica

Citation

Bojović, M. \& Bajić Šestović, J. (2020). Self-managing Socialism and its Space: Blok 5 and Challenging Rhetoric of Flexibility. ACE: Architecture, City and Environment, 15(43), 9213. DOI: http://dx.doi.org/10.5821/ace.15.43.9213

\footnotetext{
${ }^{1}$ Architect, Ph.D. Candidate, Teaching Assistant, Faculty of Architecture, University of Montenegro, Podgorica, Montenegro, ${ }^{2}$ Architect, Ph.D. Candidate, Teaching Assistant, Faculty of Architecture, University of Montenegro, Podgorica, Montenegro. Contact e-mail: marijabojovic.office@gmail.com, marijab@ucg.ac.me
} 


\section{Introduction}

"Architecture is the visible sign of customs and morals of a nation, of its taste, of its intentions: architecture, maybe more than any other art, leaves a permanent trace of one nation's state of intellect, its vitality, its energy, or its decadence."1 (Viollet-le-Duc, 1872, in Kopp, 1975, pag. 1)

The following paper is, to a large extent, a response to a continuous, general concern about the state of Montenegrin society and the totality of both natural and created space. Namely, for almost thirty years now, Montenegrin society has been undergoing the transition that impoverished all the complexity of society in the first place, but also the complexity of space, cities and works of architecture, thus reducing them to goods - assessed by their exchange (quantitative) value, rather than their use (qualitative) value. Simultaneously, a User of space has been degraded and reduced to a Buyer, rather than being a Creator, or an active participant in the process of creating relevant urban and architectonic ambiences. The transition implies the change of socio-economic-political system, i.e. the shift from the self-managing socialism to the neoliberal capitalism, occurring soon after the dissolution of the Socialist Federative Republic of Yugoslavia² - SFRY in 1989.

The implementation of social transformation in Montenegro ${ }^{3}$ has been traumatic for all the segments of society and space. In this intermediate space between the two socio-economic-political systems, it is the general, urban, everyday life that, among other things, has been damaged. The actual system of values has been impoverished, or almost scathed, the needs have been strategically homogenised and reduced to the need to possess, while the society and individuals have been degraded to the one-dimensionality (Marcuse, 1968). Such a society - the one-need society - is characterised by the absence of radical, motivational needs (Heller, 1981) and, consequently, by passivity and lack of interest for the issues related to the city and architectural space. This represents an adequate precondition for an acute accumulation of private capital, its ever faster turn-over and the creation of major profit. Given that the urban space makes for the most convenient medium, what we have, as a consequence, is the degradation of the overall natural and urban space.

In addition, transition-related redistribution of social wealth, including space, through various types of privatisations, followed by selective implementation of constitutional and legal norms, caused an extreme segregation of society which immediately started to affect the space, thus degrading it in the domain of both natural and constructed. Manifestations of this have been numerous. For two decades already, Montenegrin cities have been facing illegal construction at the outskirts, as well as in the residential city blocks; waste of the last free spaces and green areas within the urban tissue; disposal of city landmarks and cornerstones of collective memory, which had been replaced by generators of private profit; extinguishment of city nucleuses, followed by artificial foundation of new nucleuses in the vicinity of shopping malls, surrounded by "the dormitories", that emerged driven by

\footnotetext{
1 "L'architecture est le signe visible des mœurs d'une nation, de ses gouts, de ses tendances: plus que tout l'autre art peut-être, elle laisse une trace durable de l'état intellectuel d'un peuple, de sa vitalité, de son énergie ou de sa décadence" Violet le Duc, 1872, original, in French In KOPP, A. (1975). Changer la vie, changer la ville. Paris, France: U.G.E.

2 Following a relatively short period of state independence of Montenegro, internationally recognized at the Berlin Congress in 1878, Montenegro became, as of 1918, an integral part of Yugoslav federations: Kingdom of Serbs, Croats and Slovenes (1918-1929); Kingdom of Yugoslavia (1919-1941); Federal People's Republic of Yugoslavia (1945-1963); Socialist Federal Republic of Yugoslavia (1963-1992); Federal Republic of Yugoslavia (1992-2003); The State Union of Serbia and Montenegro (2003-2006).

${ }^{3}$ Montenegro is a Mediterranean country, with the smallest surface area at the Balkan peninsula, totalling only $13812 \mathrm{~km} 2$ and with the population of 625266 citizens (according to the 2011 census by MONSTAT). Its favourable strategic position at the Mediterranean contributed to its tumultuous history, whereby different conquerors superseded one another, and various cultures were shifting, each embedding itself in urban and cultural identity of Montenegro. Uneven development of Northern, Middle and Southern Region triggered an abrupt inflow of population in the capital of Montenegro - Podgorica, and at the seaside - causing a demographic misbalance, being particularly acute in the period of transition (Statistical Office of Montenegro, 2011).
}

ACE, 15 (43) CC BY-ND 3.0 ES | UPC Barcelona, Spain | Self-managing Socialism and its Space: Blok 5 and Challenging 2 Rhetoric of Flexibility. DOI: http://dx.doi.org/10.5821/ace.15.43.9213 
the market; waste of the very coastline and islands by poor planning and construction of tourist capacities; devastation of national parks for the sake of short-term profit.

In this general impoverishment (González Romero and Pérez Bourzac, 2018), the question of dwelling as the central issue has been fully deprived of its spiritual dimension of living in a city, which points at the necessity for a renewed, fundamental contemplation about it (Supek, 1987).

By use of the example of Blok $5^{4}$ (1977), the collective residential complex in Podgorica, through a brief case-study, this paper will provide the analysis and the snapshot of Montenegrin space, while highlighting one part of transition-related socio-spatial problems that Montenegrin cities have been facing. Architectural space of this residential complex and its transformations in time will serve as indicators of the relationship culture of the community and the society towards space. By all means, the paper intends to, ultimately, point at possible guidelines for overcoming these and similar (transition-related) processes of degradation.

\subsection{On Dwelling}

Dwelling is an act of culture. By this we mean that an adequate level of development of cultural values and needs, embedded in individuals and society is a necessary precondition for having an affirmative, active and participatory relationship towards one's own housing space and space, in general. This stance is partially relying on Lefebvre's thesis about the production of space (1974), since the space we create is our own reflection in the mirror. We consider that reflection - that image to be conditioned by the level of the society's civilizational development, as well as by the responsibility of individuals towards the community, and vice versa, and the responsibility of us all with respect to the collective agreement, laws and their implementation. In general, Henri Lefebvre's thesis on the production of space and the right to a city served as a starting theoretical point of this research, which will at a later stage be justified by the analysis of the very Blok 5 , as a strategically singled out extract in the spatial practice.

In the general subdivision of needs into radical ones - qualitative, collective, cultural needs and, on the other hand, material ones - quantitative needs, Heller associates material needs to capitalism and consumerist society, given that their attainment and fulfilment is in function of acquiring and fostering private property - these are linked to possession. Qualitative needs should incarnate the values which cannot be satisfied in the one-dimensional and alienated capitalist society, so they rather point at striving beyond this society, towards liberation of humans as individuals (Heller, 1981). Human rich in qualitative needs is called by Lefebvre (Lefebvre, 1988, pag. 136) a "total", yet a "free" human, who actively participates in the totality of issues related to his dwellings, that is his city, but his living space, as well, which is important for the overall course of this research.

Since the very beginnings of dwelling - settling in a certain space to get shelter - there have been records on the relationship of primordial men towards the surrounding space. Back in the Palaeolithic, the role of caves was not reduced to a mere refuge, but it rather represented the site for rituals, as well as a place for exhibiting the accompanying art (Mumford, 1988). Even then, through the use of symbols and art, while sharing a common vision of better future, a Palaeolithic man felt the need for a continuous improvement of his living space, striving towards a more meaningful and, aesthetically, more elevated life. Supported by his shelter, he created the forms, testifying about his thoughts and

\footnotetext{
${ }^{4}$ Blok 5, a collective housing complex in Podgorica, is considered to be one of the most notable examples of Socialist Modernism in Montenegro. In the internet era, when our urban everyday life is shared online, having a presence of its own, numerous photographs have been published by inhabitants of Blok 5, strongly identifying themselves with their neighbourhood and the sense of place. Due to the intriguing and sharp aesthetics of the buildings, massive and cantilevering volumes in concrete, photographs of Blok 5 are often "tagged" under brutalism.
} 
imagination, as well as social relationships - there was the need to see the space through the lenses of spiritual dimension of existence (Supek, 1987).

The role of the level of development of cultural and civilizational prerequisites for the overall prosperity of a country, i.e. the prosperity of its society and the pertaining space, is undeniable. Given that every society, that is, every mode of production, produces its own space (Lefebvre, 1991), cities and architecture represent a veritable reflection of that society, while their quality depends on the quality of the society that created them, that is on the level of development of its system of values and needs.

Therefore, we believe that only a society rich in qualitative, radical, motivational needs can have an affirmative relationship towards the space it possesses, or it uses, while making adequate use of it and improving it, in doing so. And vice versa.

\subsection{On Open Work from the 1960s}

In the 1960s, the tradition in art started to be abandoned and artists went on to insist on a major engagement of the audience, thus leaving their works unfinished and subject to the interpretation of the User (or even leaving it to chance), without setting up a single, unique and definite order and solution, but rather evoking a multitude of possible responses, instead (Eco, 1989).

Umberto Eco (1932-2016) defined such artwork as an open one (Eco, 1962), emphasising its importance, as much for the long-lasting historical utility of its concept of openness, and with that, adaptability and popularity, as for its extraordinary way of anticipating the key topic in theory of art from the mid-1960s to date- insisting on the element of multiplication, multitude or polysemy in art (Eco, 1989). The emphasis is on the role of the User, his/her interpretation and feedback, that is the interactive process between the User and the work of art. The poetics of open work advocates "the act of conscious freedom" (ibid, pag. 4). The openness, on the other hand, is "the guarantee of a rather fulfilling, overwhelming sense of satisfaction, which our civilisation has been pursuing as one of its most precious values, given that every single aspect of our culture invites us to imagine, feel and see the world around us as a multitude of possibilities" (ibid, pag. 104). Such work of art represents an ever-lasting, active process of development - "work in progress" (ibid, pag. 23). The richness of experience lies within the endless multitude of options. The User, according to Eco (1989), should never have the same perception of the same (open) work more than once, since it represents the sea of open possibilities.

Milorad Pavić (1929-2009) wrote the "Dictionary of the Khazars" (1984) in a manner allowing for a plethora of possible endings - by changing the way of writing, he aimed to change the way of reading. Every sentence in the book was composed so as to be approachable from different sides, and the parts of the book may be read in any order. Actually, most of the creative energy was invested in providing for this opportunity - the writer wanted this book to be accessible in the same manner as a sculpture. And when it comes to sculpture, Calder went one step further - his sculptures are mobile and they represent "the work in motion", which incessantly shifts its spatial forms, thus creating every time its own new space and the forms fulfilling it (Eco, 1989).

In 1960s, European art scene was, among others, influenced by Yona Friedman, a French architect of Hungarian origin, famous for his utopian projects that required significant engagement by users. In his first manifesto "Mobile Architecture"5 (1958), previously presented at Tenth International Congress of

\footnotetext{
5 “Manifesto de l'Architectura Mobile" Friedman's preparation for $10^{\text {th }}$ CIAM in Dubrovnik, Croatia, 1956.
} 


\section{ACE Architecture, City and Environment}

Modern Architecture - CIAM in Dubrovnik ${ }^{6}$, he advocated the new kind of mobility of users of space, who were given the freedom to decide. Such (residential) architecture represents "housing in line with the occupants' decision", given that the enabling infrastructure is "neither determined, nor determining"? This right to freedom, the right to individualisation within socialisation, the right to the dwelling and to dwell, the right to the artwork and participatory activities and the right to appropriation - all these are contained within Lefebvre's formulation of the right to the city (Lefebvre, 1968).

In his project "Spatial City" (1958), Friedman proposes spatial, infrastructural matrix, representing an optimum possibility for achieving unity through use of space for collective housing. User is again given the decisive role, equally important as the architect's. What Friedman advocates is almost an extreme, since he considers that a work of architecture, designed in such manner, excludes the necessity of having a preconceived plan, but it is rather the User the one ultimately designing it, with possible participation of the Architect ${ }^{8}$ (Figure 1). The design of the Friedman's ideal city only gets perfected by its use, thus leading us to conclusion that he believed in ideal users, that is citizens.

Figure 1. Spatial city. Y. Friedman

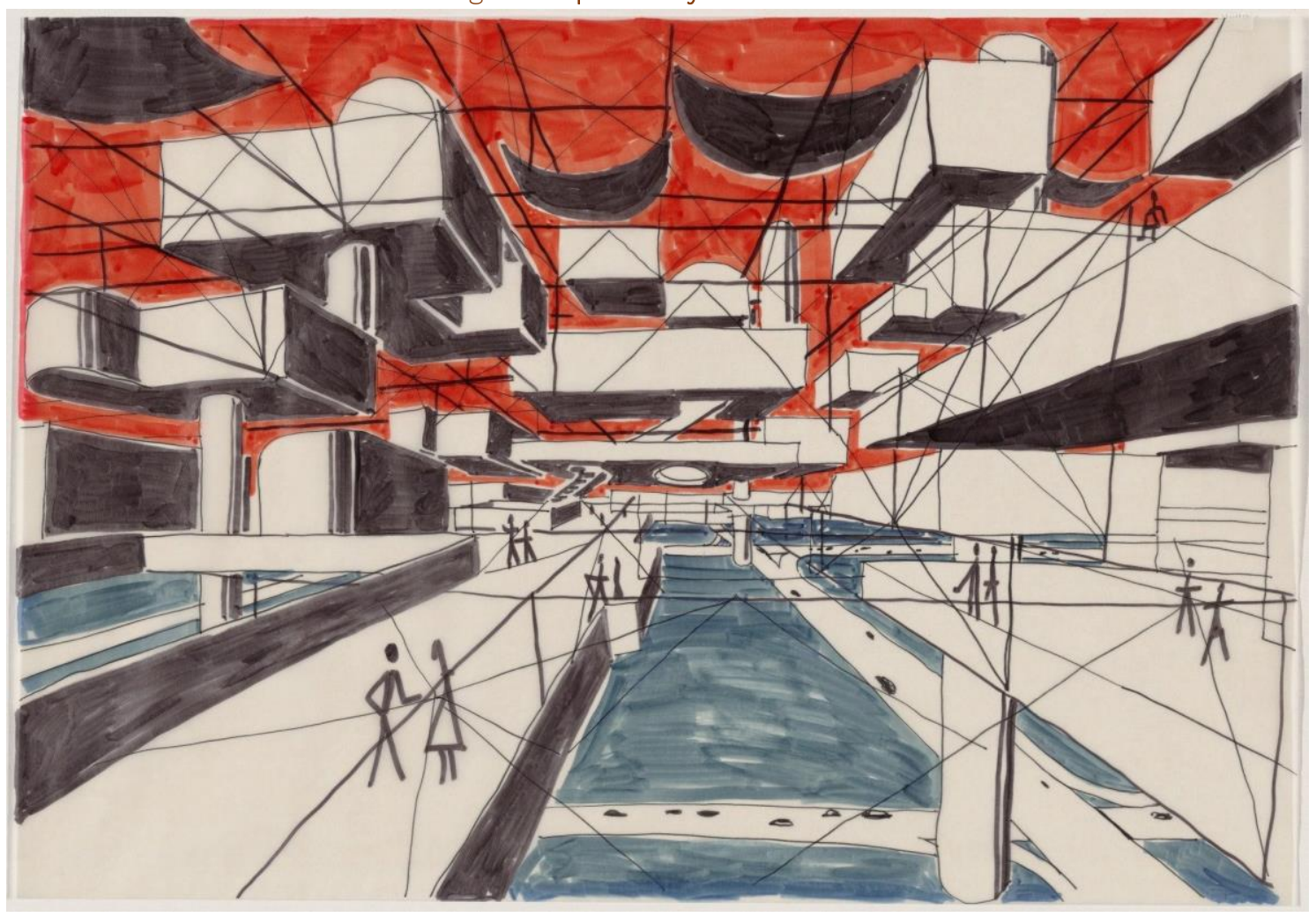

Source: Moma.org. Retrieved from

https://www.moma.org/collection/works/104695?artist id=8109\&locale=en\&page=1\&sov referrer=artist

\subsection{Rethinking of Collective Housing}

In those very years, John Habraken (1928), a Dutch architect and a theorist, born in Indonesia, wrote his key work, "Supports: An Alternative to Mass Housing" (1962), being revolted by the senselessness

\footnotetext{
${ }^{6}$ Dubrovnik, Croatia.

7 Retrieved from https://www.moma.org/collection/works/800?artist id=8109\&locale=en\&page=1\&sov referrer=artist

${ }^{8}$ Retrieved from https://www.moma.org/collection/works/800?artist id=8109\&locale=en\&page=1\&sov referrer=artist
}

ACE, 15 (43) CC BY-ND 3.0 ES | UPC Barcelona, Spain | Self-managing Socialism and its Space: Blok 5 and Challenging 
of housing industry policy-making (Habraken, 1972). He analysed negative sides of collective housing in the Netherlands - uniformity, monotony and the absence of users' participation in the process, advocating his principal hypothesis - that it is exactly the introduction of a User into the overall housing process what should dictate, that is, significantly influence, the designer's decisions and work.

A solution to the "senselessness" of collective housing, Habraken finds in a radical alternative - a separation of Support and Infill, that is a separation of collective housing in two parts - an infrastructural one, representing support, which is permanent and belonging to the domain of public responsibility, and the one in the domain of private responsibility, which is Infill-related, that is the individual part, subject to changes (Bosma et al., 2000). Public participation and the User's freedom of choice are the principal objectives that Habraken stands for in his concept. ${ }^{9}$

Support is about the frame - the very constructive composition of the building. Infill entails partition walls, bathroom, kitchen and connections for water and gas, which are necessary for the functioning of the household elements. Such separation, according to Habraken, provides major freedom to the User in terms of organising his/her living space. While Support may be constructed as a unique project, even with a strict replication, each and every housing unit at the level of Infill would be different - which would be the very User' responsibility.

While criticising massive collective housing for its uniformity, rigidity and extreme static nature (Habraken, 1972), Habraken believes that, by separation of levels of responsibility and through adaptation of construction industry and pre-fabrication, it would be possible to reach the ideal - to change, as time goes by, the individual part. Such technological progress would enable residential buildings to change in time, in line with the changes in needs of their users, rather than being gradually abandoned (ibid.).

In addition, Habraken, as well, advocates a significant change of the architect's role in the process, since he believes that residential architecture should not pretend to be a masterpiece, but it should rather provide the possibility for growth and change (Habraken, 1988). According to him, an architect has three basic tasks that predominantly relate to the intermediation between users and construction industry - to design a structure, to advise the components' producers in the pre-fabrication phase and to be a consultant to the end user of space in terms of organisation of Infill, which, as such, is in the domain of his own responsibility. Nonetheless, an architect supervises the totality of the process. Habraken believes that this controversial and complex transformation in roles of architects and users might restore "the natural relationship" between people and their homes (Habraken, 1972).

On the other hand, the User should be given ever more rights within collective housing. Housing space, being a private, personal space, needs to be more adaptable to the individual needs and this is why it is not possible to provide a single solution that suits everybody (Habraken, 1988). This may be achieved by separation of Support and Infill.

Despite arguing that housing, as a process of solving existential problem, is universally applicable, he, nonetheless, emphasises that a necessary prerequisite for its successful implementation is the cultivation of the process in an adequate social ambiance, entailing the initial need for cultivation on behalf of every individual, beforehand (Habraken, 1972).

\footnotetext{
${ }^{9}$ OpenBuildings.com, Foundation. Retrieved from https://www.openbuilding.co/foundation 


\subsection{Actualisation of the Concept of "Open Work"}

Based on the philosophy developed by Habraken, Dutch architects in mid 1990s established the Open Building group, believing that the open building concept had been too advanced for its epoch. Nowadays, it is becoming clear that the design principles of such flexible buildings are actually valuable tools for transforming traditional construction industry into sustainable and resilient cities. Open Building Network, that was originally Dutch, today counts more than three hundred members worldwide.

The Network is committed to the radical transformation of construction industry and constructed environment, in general, aimed at achieving sustainable and individualised way of living. The reasoning behind partially relates to the domain of sustainability, as the key imperative of today, but it also tackles the social aspect - Open Building stands for a shift from the consumerist society into a society that would be based on participation, inclusiveness and engagement of all the stakeholders into the decision-making process ${ }^{10}$.

Therefore, open buildings represent a playing field for appropriation and co-creation. They provide infrastructure to their users and owners of the apartments as a basis for further creation of their personal space. This concept entails the participation on behalf of the User in early stages of the design, thus boosting a strong sense of belonging to the community. Open building is an open process. Life cycle of these buildings is significantly prolonged, given that they are open for changes over time, thus assuring their up-to-datedness and adequacy in the long term. In the Netherlands, a great number of such buildings of residential character has already been successfully realised. Open buildings "accommodate social, economic, and technological complexity of our and future time, they add value and are timeless"11. Only this kind of architecture complements the contemporary society, which is unstable, uncertain and unpredictable (Tschumi, 2004)).

\section{Case Study: Blok 5 (1977) as a Social Experiment}

It is exactly in line with the open building principles, engaging users into the decision-making process about their own housing space and practicing the right to a city and a residential space, that Blok 5 a collective residential complex in Podgorica, was designed (1977). Since Montenegro was, back then, one of the six members of the self-managed Socialist Federal Republic of Yugoslavia, such an endeavour and a social-spatial experiment was aligned with the reigning social system, advocating major participation of individuals in decision-making at all levels ${ }^{12}$. Being open and flexible, Blok 5 was only partially designed for the generation of that time, and predominantly for future generations.

\subsection{Spatial Context}

The location envisaged for the construction of Blok 5, its surface being 4,5 hectares, represented a logical sequence of urban development of the then Titograd ${ }^{13}$, the capital of Montenegro, along the

\footnotetext{
${ }^{10}$ OpenBuildings.com, Manifesto. Retrieved from https://www.openbuilding.co/manifesto

11 Ibid.

12 Self-management ideas have nowadays regained their popularity - Barcelona En Comú, citizen-focused democratic platform, in the chapter on its Principles, states that "decisions must be taken, whenever possible, by the people themselves. When it is necessary for decisions to be taken indirectly, this should be done by representatives' subject to oversight." Retrieved from https://guanyembarcelona.cat/wp-content/uploads/2014/06/priciples.pdf

13 Titograd - name of the capital of the Republic of Montenegro during the socialist Yugoslavia, in the period between 1946-1992.
}

ACE, 15 (43) CC BY-ND 3.0 ES | UPC Barcelona, Spain | Self-managing Socialism and its Space: Blok 5 and Challenging

Rhetoric of Flexibility. DOI: http://dx.doi.org/10.5821/ace.15.43.9213 


\section{ACE Architecture, City and Environment}

e-ISSN 1886-4805

main axis, "via principalis" - the city's urban backbone, connecting all the three urban structures: Stara Varoš, Nova Varoš (Mirkova Varoš) and the city "over Morača” - "The New City” (Figure 2).

Figure 2. The position of Blok 5 in the urban matrix of Podgorica

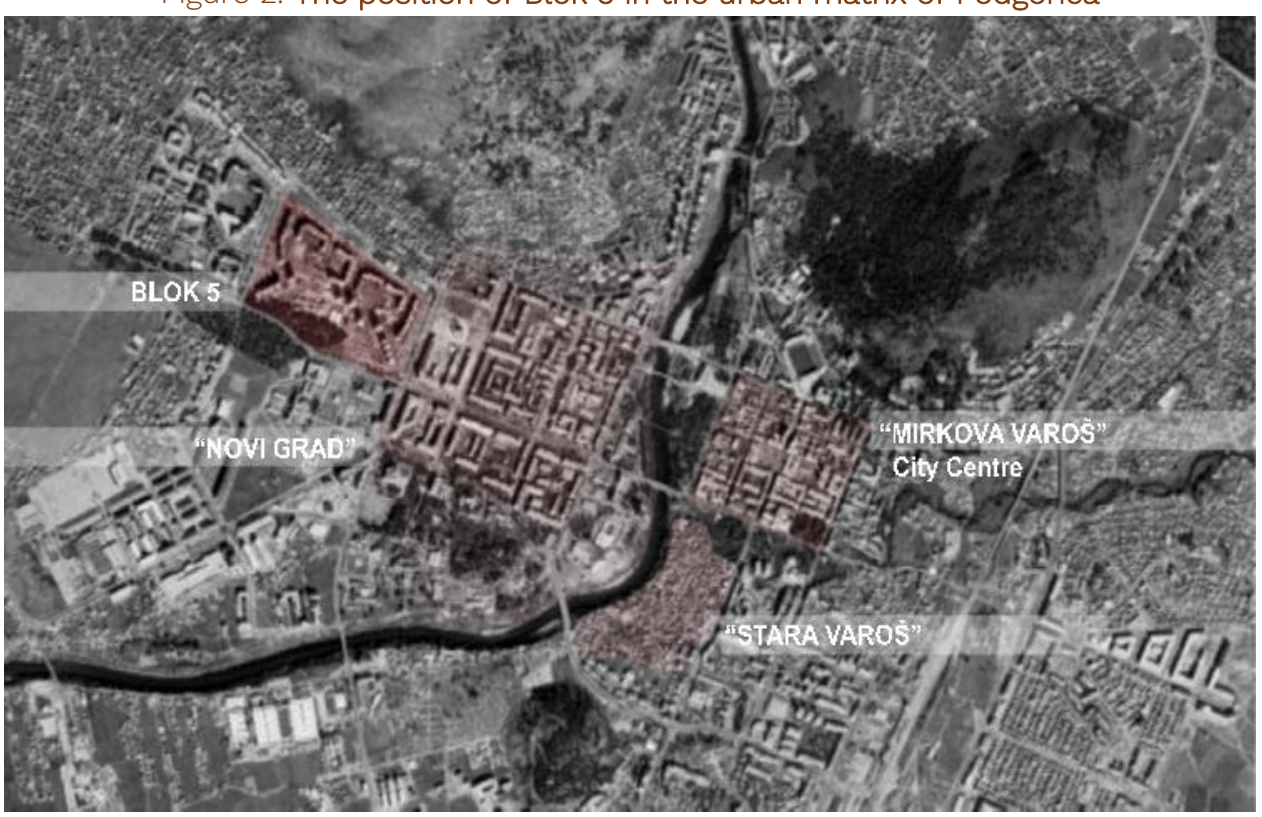

Source: Own elaboration by authors.

After the uncontrolled development of Stara Varoš, as a commercial-artisanal centre, that started in the late $15^{\text {th }}$ century during the Ottoman period, followed by the planned development of the orthogonal matrix of Mirkova Varoš, in line with the design by the Russian engineer Vladimir Ivanovich Vorman as of 1879, and following the renovation of the city after World War II, Podgorica started expanding to the right riverside of Morača ("The New City”) (Kalezić, 1967; Republički zavod za urbanizam i projektovanje, 1973; Ivanović, 1974; Urbanistički institut SR Slovenije, 1989).

"The New City" space, including Blok 5, has been recognised by various planning documents as the area suitable for the development of housing (General urban plans as of 1957, 1964 and 1974), having favourable natural-morphologic characteristics and a logical transport connection with the central urban nucleus.

\subsection{Self-managing Socialism as the Social Context}

Montenegro, as one of six members of the federation of South-Slovene republics - Socialist Federal Republic of Yugoslavia - SFRY, was, in terms of organisation, a top-bottom, socialist (later also selfmanaging) republic, which considered space as its most valuable resource, beside its people, and a very essence of the state's existence. Along with such concept of state policy, the process of urban design and planning took the primary role in distribution of public (city) space.

After rejecting Stalin's totalitarian idea of socialist realism or communism, the concept of selfmanagement, formulated by Edvard Kardelj, became the foundation of socialist development of the society, based on reinforcing the humanist ideas of production and public affairs (Kardelj, 1949; Milovanović, 2016). Yugoslav model of self-management based itself on major democratisation of society, valorisation of social values of equity and equality, as well as proclamation of state property - the property of all citizens. It represented the start of realisation of philosophical-sociological

ACE, 15 (43) CC BY-ND 3.0 ES | UPC Barcelona, Spain | Self-managing Socialism and its Space: Blok 5 and Challenging 
proposals and ambitions already existing in Europe since the middle of the 19th century. This model of socialism was different from models applied in other countries. Many theorists defined the Yugoslav self-management as "one of the most fascinating social projects of our time" and a first major step forward in the international social movement, recognising a worker as "a social accomplice", who has been given the possibility of controlling all the segments of his life (Marković, 1971; Kirn, 2010; Zukin, 1975).

A dramatic inflow of rural population into Montenegrin cities ${ }^{14}$, due to the accelerated industrialisation of the state after World War II, as well as the increase in number of urban population ${ }^{15}$, created the need for a more intense residential construction. Basic principles of housing fund construction were grounded in the values of the self-managing socialism "to everyone, according to their work" and "to everyone, according to their needs" (Petranović, 1988, pp. 120-160). Residential construction was implemented in line with the Law on Nationalisation of Rental Buildings and Building Land, the Law on Housing Relations and the Law on Housing Units, all this with the aim of "housing measured to meet socialist human needs".

Following the housing policy reforms in 1974 and the adoption of the SFRY Constitution that introduced self-management across sectors, residential construction started to be implemented through "SIZ" - self-managing communities of interest ${ }^{16}$. In this way, representatives of citizens users of the apartments and representatives of social enterprises - investors, together made decisions on locations, on quality, quantity and price of residential buildings construction (Mandić, 1992).

Beside all the possibilities that the self-managing socialism provided to social communities, true values and quality of this social model were not used to the fullest. User was provided with material and social security and prosperity, jobs opportunity through "projected" labour market, free-of-charge health care and education, as well as the possibility of "participation in decision-making". However, critique of the self-managing socialism would imply an unsatisfactory level of system development and the "stiff" way of decision-making. The ideas were "imposed" from the top of hierarchy, without contact with the specific user of space, who would leave his participation to "the representative". Rigid socialist housing policy often created monotonous, uniform housing fund, insisting on "a collective social identity", which was not the case with the Blok 5 design.

\subsection{On Praxis}

In the ambiance of self-managing socialism, at the beginning of 1977 in the SFR Yugoslavia, the competition call was opened for the design of a collective residential complex in Podgorica, in line with the already adopted detailed master plan ${ }^{17}$ as of 1975 . The award-winning competition entry by

\footnotetext{
${ }^{14}$ A noticeable decrease of the rural population shares in the total population, as it dropped from $71,2 \%$ in 1952 to $13,5 \%$ in 1981, to reach only 7,5\% in 1991 (Marković, 1971).

${ }_{15}$ Montenegro recorded the highest extent of urbanisation of all the South-Slovene states. Residential housing doubled in the period 1955-1958 (Housing Policy Reform, 1959). By the end of World War II, due to heavy bombings, Titograd was reduced to only 5500 inhabitants; In 1948, their number grew to 10388. In 1953, the census recorded 15496 of inhabitants, whereas in 1961, this number almost doubled - to 29217 (Marković, 1971).

${ }^{16}$ Since 1974, following the adoption of the Constitution that introduced self-management across all the sectors, including the housing, residential construction had been implemented through "SIZ"- self-managing communities of interest "Working people - directly, or through their associated labour organisations - establish their self-managing communities of interest in housing area..." In SIZ-es, the funds are jointly collected for residential construction, the policy and action programme are defined, residential buildings and social property apartments are managed in cooperation with the residents (Milošević, 1959, pag. 59).

17 Lead urban planner, responsible for the detailed urban plan of Blok 5, was the architect Vukota Tupa Vukotić. The plan was processed by the Republic Institute for Urban Planning and Design. Much similar to nowadays situation, the authorship in urban planning was non-existent.
}

ACE, 15 (43) CC BY-ND 3.0 ES | UPC Barcelona, Spain | Self-managing Socialism and its Space: Blok 5 and Challenging 9 Rhetoric of Flexibility. DOI: http://dx.doi.org/10.5821/ace.15.43.9213 
architect Mileta Bojović18 was submitted under "PRAXIS", which indicated the ambition of achieving the unity of theory and practice.

For the sake of consistency of the research narrative and in order to point at the unity of theory and practice at the example of Blok 5, it is important for this paper to emphasise the connections of the architect with France, in those key 1960s, when Paris (1968) became the most significant place in the world for the development of sociological thinking on cities and a particular kind of cultural revolution. Beside his work in practice ${ }^{19}$, Bojović studied at the Institute for Urbanism in Paris, where he acquired theoretical knowledge on urbanism and urban sociology. One of the professors at the Institute was Henri Lefebvre, the unparalleled authority for philosophy and urban sociology, later to become his mentor for the university doctoral thesis in the framework of the Department in Nanterre, entitled "Urbanism and Architecture in Yugoslavia Between Self-Management and the Withering Away of the State”, (Blagojević, 2017).

At the Institute for Urbanism, Bojović, according to his own words, gained insight into Plato's and Aristotle's philosophy and theory about the city - polis, which would be further developed by Lefebvre in his key works "Production of Space" (1974) and "The Right to the City" (1968). Final part of his lectures at the Institute referred to the critique of the capitalist city that subordinated all to profit, while swapping its usable value for the market value.

The envisaged solution to this was through self-management at all levels, actually pointing at the initiated Yugoslav experience ${ }^{20}$, Bojović stated. The famous May 1968 protests of students actually started from Nanterre, from Lefebvre' Sociology Department - all the students were oriented towards Marxism, Socialism and Self-Management.

In those years, Paris was the research centre of art (Blagojević, 2017). Top-level artists - painters, sculptors, musicians, authorities in the world of theatre and ballet, they were all working at, or rather frequently visiting, the capital of France. Anatole Kopp was publishing his works on Russian Architectural Avant-garde and Constructivism. Daniel Guérin was writing about anarchists, Bakunin and anarchist ideas which he followed all up to the self-management in Yugoslavia, as well as about the Chinese research and experience. Mao's "Little Red Book" was popular, and advocating, inter alia, that the young people who acquired high education should turn to their hometowns and work on their education and development, i.e. their improvement (ibid). Their common efforts were directed at synthesis and abolishment of borders between arts, as well as their inclusion, activation, and their reconcilement.

In the self-managed Yugoslavia of 1977, in the period when an open work in art was ultimately popular at European cultural scene, the design of Blok 5 was created. The focus was, according to the

\footnotetext{
18 Mileta Bojović (1941, Zminica, Municipality of Žabljak, Montenegro) is one of the most prominent Montenegrin architects of the second half of 20th century. He obtained a number of prestigious distinctions and professional recognitions over his long and rich career. In parallel with practice, he has actively published work in the field of urban sociology. Bojović is a member of Montenegrin Academy of Science and Art (CANU). At that very moment (1977) Bojović was employed at RZUP (Republički zavod za urbanizam i projektovanje; Republic Bureau for Urbanism and Architecture) in Titograd. The competition call was "by invitation" and The Republic Bureau had submitted three competition entries, one being the winning and further realised one.

19 "Bojović took an internship in the atelier of the architect Jean Marconnet in Nancy in 1964-5, working on the project for the rehabilitation of the local quartier Saint Sébastien. After graduating at the Faculty of Architecture in Belgrade in 1966, in 1967-8 he works in Paris in the atelier of the Grand Prix de Rome awarded architect Jean Faugeron, ÉNSBA professor, and collaborates on a number of striking projects, from the Les Halles in Paris to the French Pavilion at the 1967 Montréal World Expo." (Blagojević, 2017, p.142)

${ }^{20}$ Lefebvre was present in Yugoslavia of that period, as a counsellor of SFRY top state leadership and a participant to the Summer School in Korčula, Croatia, along with Marcuse. The organisers of this Marxist-oriented summer school were also publishers and editors of the journal Praxis.
}

ACE, 15 (43) CC BY-ND 3.0 ES | UPC Barcelona, Spain | Self-managing Socialism and its Space: Blok 5 and Challenging 10 Rhetoric of Flexibility. DOI: http://dx.doi.org/10.5821/ace.15.43.9213 
architect, on people, on the role and the position of User, who was a central figure towards which were "gravitating" both (urban) plans and the city. By means of this design, the author started his own research of postulates on relationship between people, society and the city, which preserved their continuity throughout humankind history and which were the subject of Lefebvre's cult work "Production of Space".

\subsection{The Design and Levels of Flexibility}

The Competition programme required a specific number of apartments and strict obedience to the pre-defined square footage for each type of apartment, following the standards for social housing. By using the 6x6-meter module and combining it in various ways, the architect managed to meet all the criteria prescribed by the programme.

The designed housing units varied in structure from a studio (36m2) to a four-room apartment (108m2). The total number of units was 1800. The design, in line with Detailed Master Plan, envisaged commercial premises on the ground floors of some buildings (Figure 3, Figure 4).

Figure 3. Apartments Typology: two and three-bedroom apartments
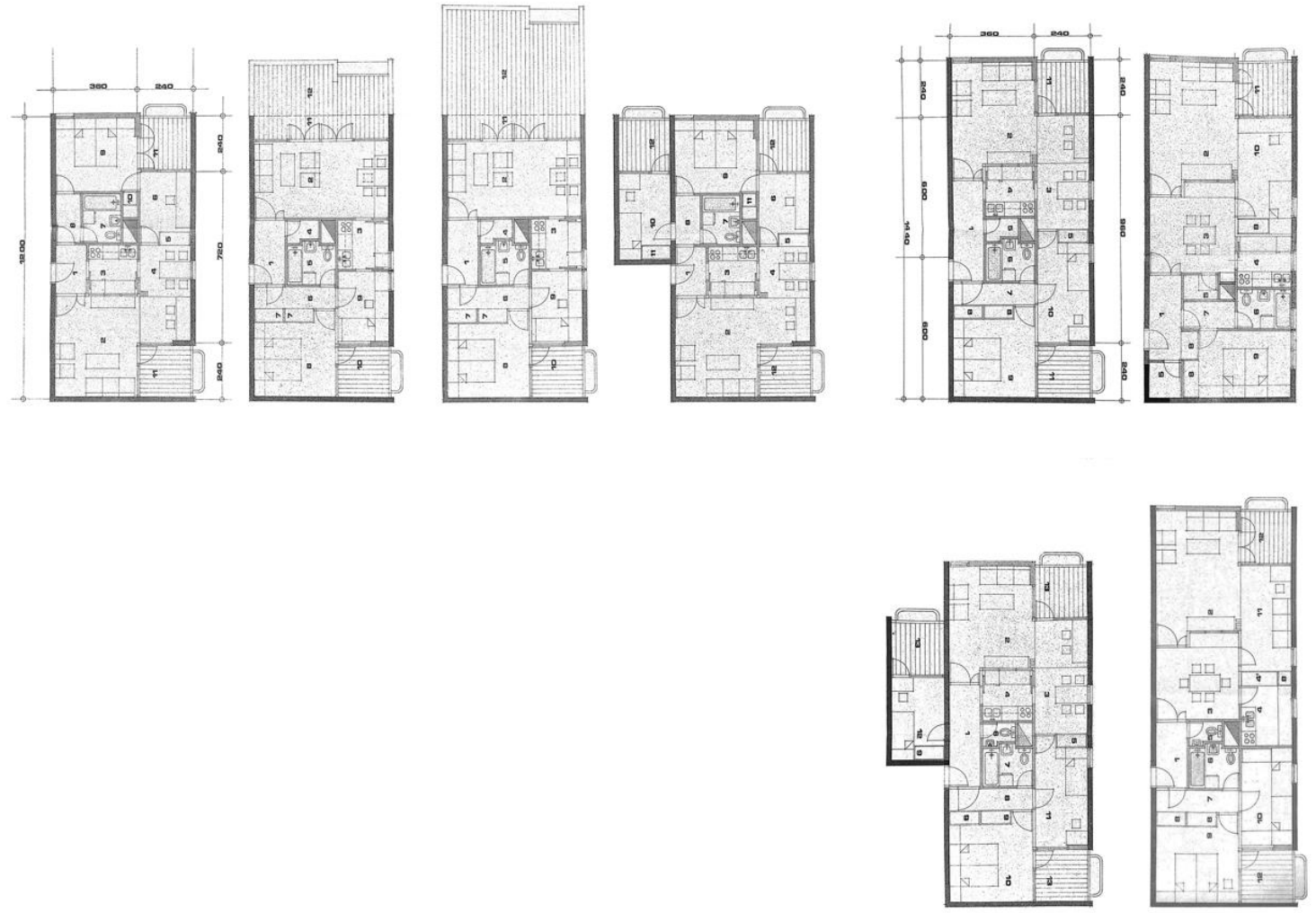

Source: REPUBLIČKI ZAVOD ZA URBANIZAM I PROJEKTOVANJE. (1978). Dispoziciono rješenje - šeme prodaje sa tipologijom stanovanja, Blok 5 - zgrada D2. Titograd, Crna Gora: SIZ stanovanja Titograd. [REPUBLIC BUREAU FOR URBANISM AND ARCHITECTURE (1978). Apartment typology, Blok 5; Titograd, Montenegro: SIZ Housing Titograd]. 

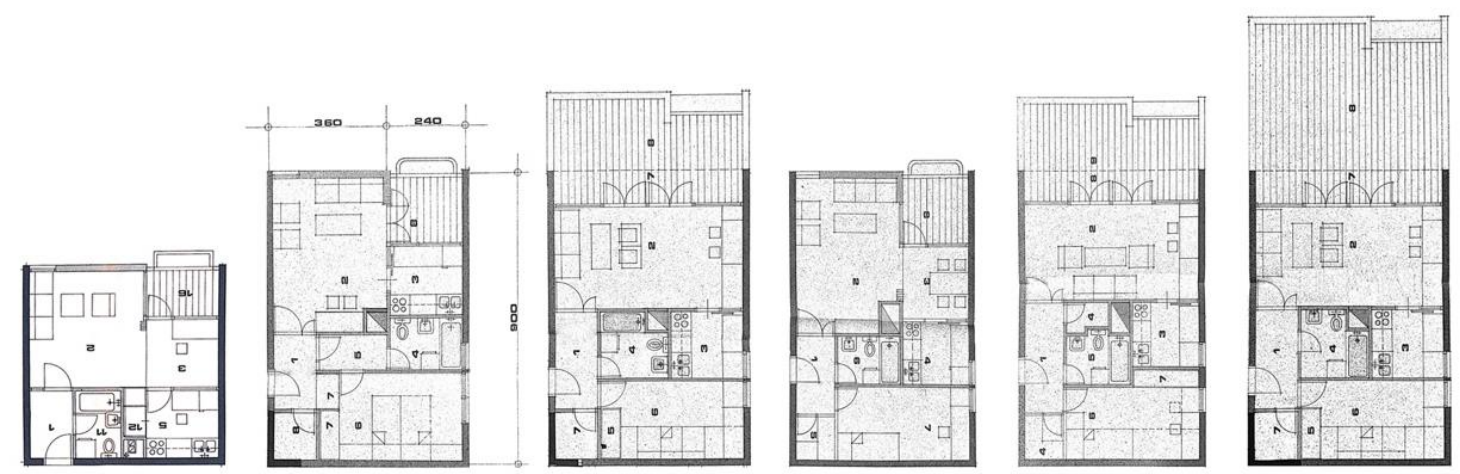

Source: REPUBLIČKI ZAVOD ZA URBANIZAM I PROJEKTOVANJE. (1978). Dispoziciono rješenje - šeme prodaje sa tipologijom stanovanja, Blok 5 - zgrada D2. Titograd, Crna Gora: SIZ stanovanja Titograd. [REPUBLIC BUREAU FOR URBANISM AND ARCHITECTURE (1978). Apartment typology, Blok 5; Titograd, Montenegro: SIZ Housing Titograd].

Blok 5, as the residential complex entailing thirteen buildings of various typology and extending itself over 190 thousand square meters of gross surface area, was a rather complex operation for that time and Montenegrin self-managing society ${ }^{21}$. By force of habit, it could have been implemented through monotony and simplification of all forms, that is, through unification of buildings and apartments on one side, and their dwellers, on the other. The author's ambition was exactly the opposite - through the design, buildings got individualised to the smallest of units, which should have been highlighted through a separate design of painting the facades, as a first of its kind, a technical breakthrough in Montenegro, back then already well-practiced in the world. This original colouring design was supposed to additionally emphasise the playful, jagged volumes of this residential complex, but it was stopped at the very beginning of its realization.

The quality, that to a great extent distinguished the award-winning and implemented competition design from others, was reflected in the accentuated flexibility of the buildings. The first level of flexibility referred to the structure of various types of apartments, which enabled the Investor to adapt the structure of the needed housing units, from a studio to a four-room apartment, in the framework of the same gauge of a building. The second level of flexibility referred to the possibility of changing the housing space, according to the users' needs. Considering an individual's participation crucial for creation of their own space, the architect enabled, through his design, numerous variants of apartments in advance, consisting of the same elements and covering the same surface areas, due to the well thought-through modular organisation. He provided for the variability of the façade, as well - loggias and non-constructive façades ${ }^{22}$ that could be changed over time. The design was initially allowing for meeting the needs of both the parties involved.

The accentuated dynamics of the buildings' volume, beside achieving "fragmentation" of rather robust gauges and elements of design, resulted in a number of terraces, intended for internal use or placing greenery, including loggias, screened from sun, wind and views by shutters (Figure 5).

\footnotetext{
${ }^{21}$ As a residential block, Blok 5 is equipped with necessary amenities as well (in line with the Detailed Master Plan) - the health centre (designed and built along with the apartment buildings, connecting two high-rise buildings on the ground floor level), two kindergartens and an elementary school. The school and kindergarten were built two decades later and are significantly oversized, and using large portion of open green spaces, due to the necessity of neighbouring residential blocks to use their capacities as well.

${ }^{22}$ It was possible to convert loggias into an internal space, by adding the glass glazing, if, over time, a family grew larger or a lifestyle was changed.
} 


\section{ACE Architecture, City and Environment}

e-ISSN 1886-4805

Figure 5. Blok 5. Dynamics of the volumes (1988-89)

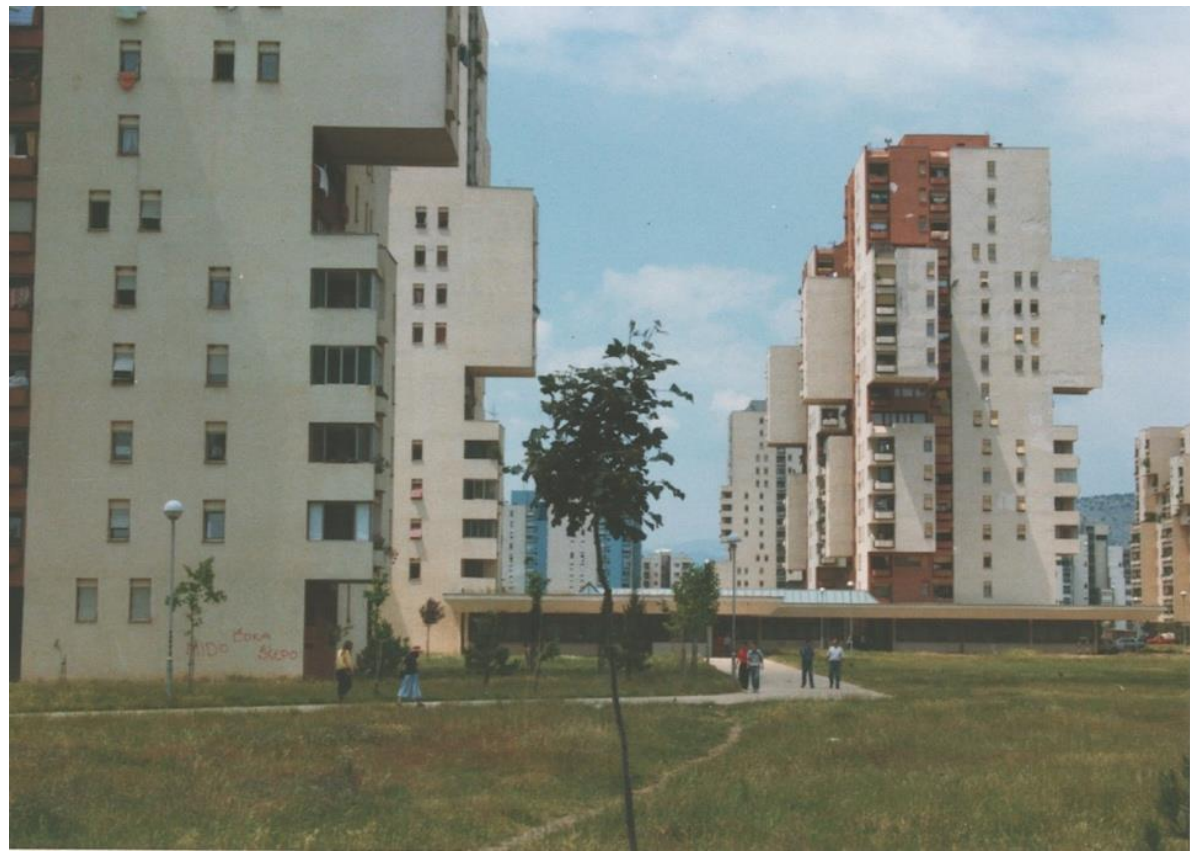

Source: Courtesy of architect Mileta Bojović.

In order for the end user to be able to adapt interior of the apartment that he was assigned, in line with the criteria and standards of allocation that were then in effect, and to modify it according to his needs, habits and wishes, the housing units were designed in such a manner to have only a sanitary and kitchen block fixed, while all the other partition walls were movable - they could unwind, change position or be completely removed (Figure 6).

Figure 6. Scheme of fixed installation block and open plan of a typical apartment
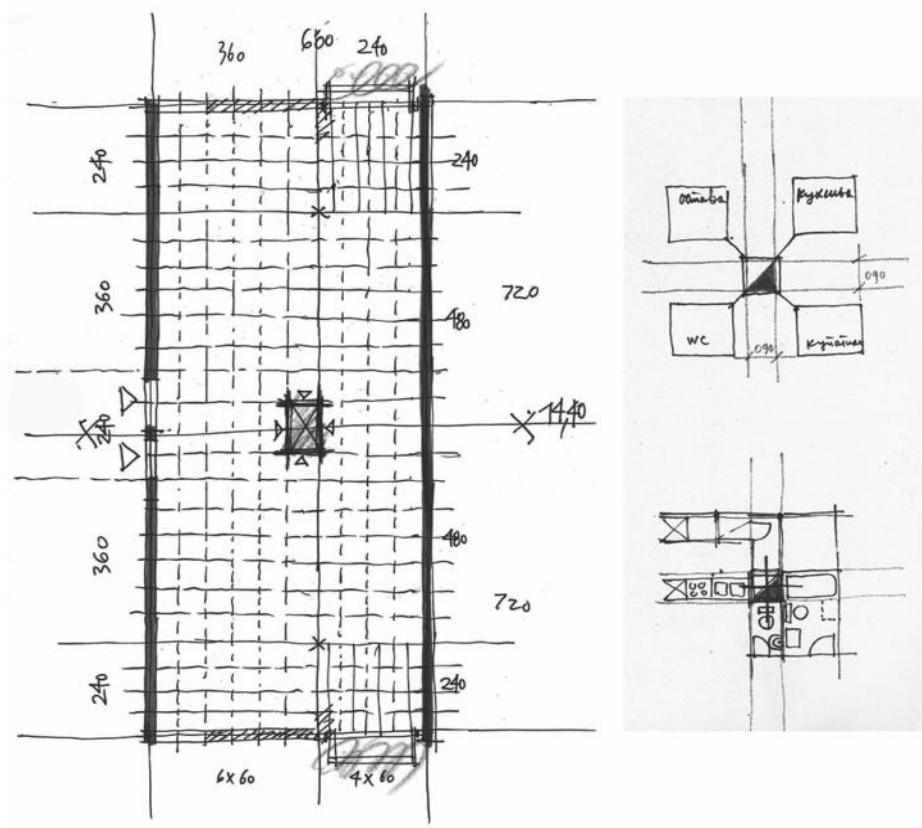

Source: Courtesy of architect Mileta Bojović

ACE, 15 (4.3) CC BY-ND 3.0 ES | UPC Barcelona, Spain | Self-managing Socialism and its Space: Blok 5 and Challenging Rhetoric of Flexibility. DOI: http://dx.doi.org/10.5821/ace.15.43.9213 
Possible solutions were envisaged by the design, while the architect was at disposal of future Users, so that their living space might be designed in the most adequate manner, both before - during the design elaboration, and after the construction of Blok $5 .{ }^{23}$

In that specific moment for Montenegro, in sociological and political sense, in the period of Yugoslav self-managing socialism, when the state politics entailed the participation of individuals in the decision-making, in particular when it comes to events from their work life or living space, the procedures were, however, carried out by the intermediation of representatives. Self-managing community of interest was the organiser and the investor of the entire Blok 5 venture, yet, at the same time, it was the bureaucratic obstacle, preventing direct contact between the architect and the future users of the apartments. Representatives of SIZ, which advocated on behalf of the users, were actually making decisions on their own and choosing themselves solutions for the apartments that were to be constructed (Figure 7).

Figure 7. Segment of D2 building, Blok 5: apartment "binding"

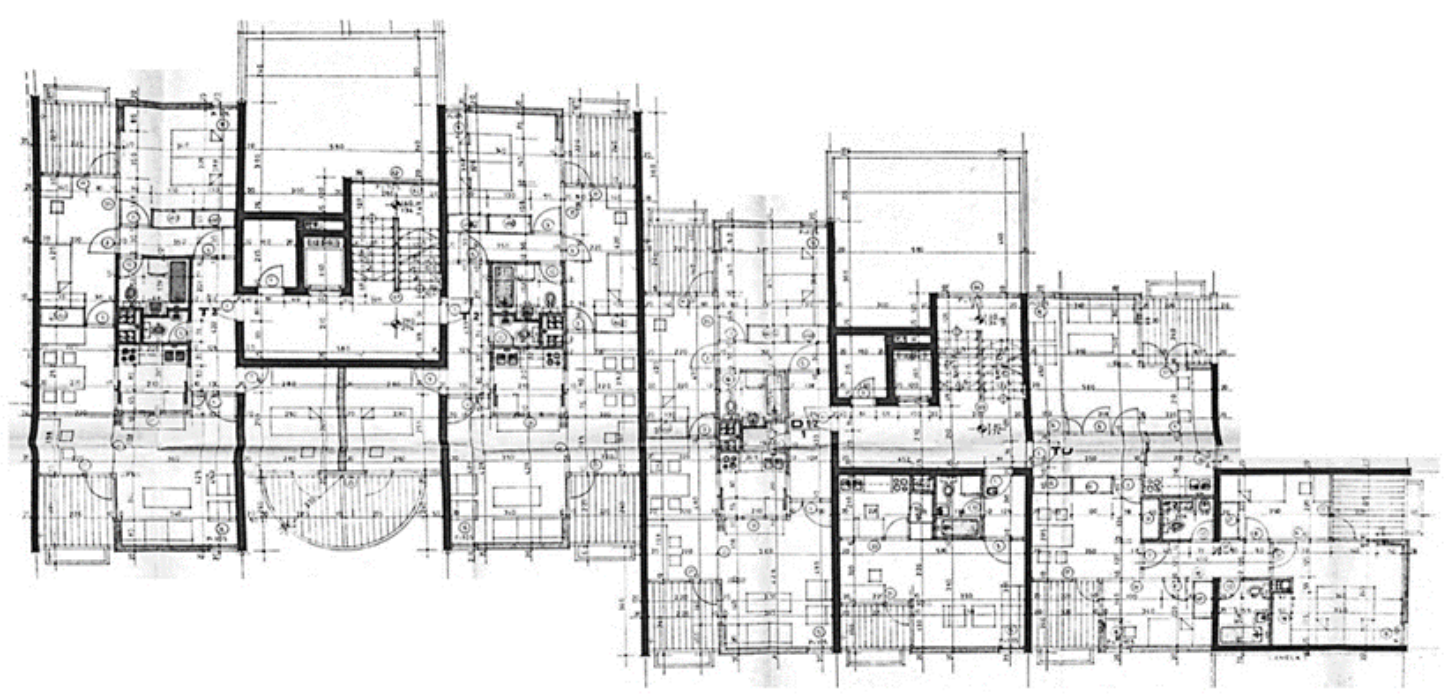

Source: REPUBLIČKI ZAVOD ZA URBANIZAM I PROJEKTOVANJE. (1978). Dispoziciono rješenje - šeme prodaje sa tipologijom stanovanja, Blok 5 - zgrada D2. Titograd, Crna Gora: SIZ stanovanja Titograd. [REPUBLIC BUREAU FOR URBANISM AND ARCHITECTURE (1978). Apartment typology, Blok 5; Titograd, Montenegro: SIZ Housing Titograd].

Regardless of these aggravating circumstances, it turned out that there was no particular interest on behalf of future residents for the changes of internal, private space, that is, for using the possibility and the right to participate in its design. There were many reasons to that - the interiors of apartments were significantly better equipped than before ${ }^{24}$, which was followed with a rather low level of living culture and the absence of habit or the need to be actively engaged in the matters of arranging their own living space.

However, it is rather interesting, if not indicative, that, in parallel, some very different scenarios, regarding users' interest to participate, were taking place in Western Europe of that time - Italy, Belgium, and Great Britain, in particular.

\footnotetext{
${ }^{23}$ According to John Habraken, an architect has three key roles to play in the process of a building's design, but following this stage, as well.

24 Due to the high level of elaboration of the prefabricated partition elements, built-in closets and kitchens, the apartment's interior was almost fully "complete".
}

ACE, 15 (43) CC BY-ND 3.0 ES | UPC Barcelona, Spain | Self-managing Socialism and its Space: Blok 5 and Challenging 
Villaggio Matteotti (1969-1975), in the suburbs of Terni, Italy, designed by architect Giancarlo Di Carlo25, in close collaboration with sociologist Domenico De Masi ${ }^{26}$, was the first Italian example of active participation of future dwellers in all the phases of the design process ${ }^{27}$. The interdisciplinary team of urban planners, architects and sociologists worked intensely with future residents, through series of interviews, meetings, and exhibitions. The aim was to transform an old and inadequate workers' village into a modern neighbourhood, in line with the personal needs and previous habits of the residents (Schlimme, 2009; De Jorge-Huertas, 2018). Although the architectural culture of future users was limited and conditioned by traditional constructions and despite the initial mistrust, the end result was an impressive catalogue of dwellings and apartments with forty-five different typologies. Di Carlo proposed the general, three-dimensional grid $^{28}$, but the variation of typologies and the frequency of units were established by the very users ${ }^{29}$.

At the same time, In Belgium, the famous MéMé (1970-1976) was designed by Belgian architect Lucien Kroll (Kendall and Teicher, 2000; Doucet, 2015). MéMé was the accommodation for students of Medicine at the Catholic University of Louvain. It was actually the students who approached Kroll (well-known for advocating the participation of users ${ }^{30}$ ) to ask for an alternative to the monotonous and more traditional design proposed by the University ${ }^{31}$. Kroll believed that their urge to participate in the creation of their future living and work space was the consequence of student protests in May 1968 and of the overall post-'68 ambiances. The design process, having emphasis on the users' needs, and followed by series of discussions, was very intense and had lasted for two years. However, despite it being a manifesto-building and a successful monument to the participatory design, La MéMé had never been fully understood and properly appropriated by the authorities of the University.

Ralph Erskine's once controversial, and now iconic, Byker Wall in Newcastle upon Tyne, was named the best neighbourhood in the United Kingdom in 201732. This Victorian-era working-class area of densely built terraces and slums was demolished in 1969, to make way for a modern, unbroken residential block - an 1,800-home estate of 9,500 people ${ }^{33}$. As the initial idea was to rehouse the original residents, without breaking the patterns of their everyday life, the Erskine's pilot scheme involved 46 households, working with architects in the design of their future homes (Walters and Brown, 2004; Erskin, 2009; Pendlebury, Townshend and Gilroy, 2009).

However, all these very famous and successful pioneering examples of participatory design in Europe have one thing in common - highly interested users, once they are given the opportunity to make decisions about their own (future) living space. Montenegrin experience with Blok 5 was quite the opposite. Although participatory design was fully in line with political ideology of that time, future

\footnotetext{
25 Italian architect Giancarlo Di Carlo (1919-2005) was founder and director of the review "Spazio e società" (1978-2001) the Italian edition of the French scientific and interdisciplinary review "Espace et Société" (1975- to date), founded by Henri Lefebvre and Anatol Kopp,published by Éditions Anthropos. The review has been dealing with issues of cities, space and politics.

${ }_{26}$ Di Carlo's collaborators on this project were the architects Faust Colombo, Valeria Fossati Bellani and Sandro Volta.

27 Terni, Nuovo villaggio "Matteotti", Giancarlo De Carlo, 1969-1975, con seguito al 1987. Retrieved from http://architetti.san. beniculturali.it/web/architetti/progetti/scheda-progetti?p p id=56 INSTANCE hlz4\&articleld=14395\&p p lifecycle=1\&p p state=normal\&groupld=10304\&viewMode=normal

${ }^{28}$ This general three-dimensional grid served as an open system enabling specific needs and requests of future dwellers to be embedded, such as garden terraces, independence of units, variations of apartment layout, etc.

${ }^{29}$ Laura Felci for Docomomo Italia. Retrieved from https://www.docomomoitalia.it/register/MF 37.pdf

${ }^{30} \mathrm{In}$ his own words - this was a lot under influence of Henri Lefebvre's writings, and "Right to the city" in particular. (From Lucien Kroll's interview with Lucas Brusco et Martial Résibois) DOI: https://doi.org/10.3917/clara.hs5.0188

31 Participation. Movement-Europe. Retrieved from https://www.spatialagency.net/database/why/political/participation.1970s

32 Byker Wall was listed Grade by English Heritage in 2007, both for its "groundbreaking design, influential across Europe and its "pioneering approach to public participation". Retrieved from https://www.theguardian.com/cities/2015/may/21/by ker-wall-newcastles-noble-failure-of-an-estate-a-history-of-cities-in-50-buildings-day-41

${ }^{33}$ Byker Wall: Newcastle's noble failure of an estate - a history of cities in 50 buildings, day 41 by Anna Minton. Retrieved from https://www.theguardian.com/cities/2015/may/21/byker-wall-newcastles-noble-failure-of-an-estate-a-history-ofcities-in-50-buildings-day-41
}

ACE, 15 (43) CC BY-ND 3.0 ES | UPC Barcelona, Spain | Self-managing Socialism and its Space: Blok 5 and Challenging 15 Rhetoric of Flexibility. DOI: http://dx.doi.org/10.5821/ace.15.43.9213 
residents were lacking an adequate level of awareness and development of living culture, to feel the need to actively participate in the process.

The spaces that did "attract attention" and were of interest to the users for their interventions, were actually common terraces of the buildings that had been designed as large, central spaces for neighbourly gatherings. Nowadays, they have all been misappropriated, partitioned, occupied... The original idea of the author, through use, got converted into its opposition - the urge for seizing and appropriating of common space became particularly evident with the start of transition, Bojovićs ${ }^{34}$ emphasised. Seizing of common terraces was only the beginning of the conquering interventions by the residents of this complex.

\subsection{Construction Process}

At the level of preliminary design, Blok 5 had been designed in the pre-fabricated system. A construction company, dealing with pre-fabrication, submitted a favourable offer, in terms of necessary time for the construction and its price. However, the State decided to concede the construction to a state-owned construction company, due to financial reasons, which was the reason why the design needed to be carried out in a classical construction system, and thus, to be redesigned.

What had remained out of the designer's original idea about prefabrication were only the internal elements - the equipment and some partition components ${ }^{35}$ were prefabricated, although the Contractor was trying to convert these, as well, in the classical construction system, by which, the original idea about the flexibility of housing units would have been completely impoverished.

Absence of full prefabrication had an impact on the buildings - a prefabricated system would have allowed for a significantly bigger extent of precision during the construction, which, for that matter, would have been much faster and cheaper.

The construction already started on October 1st 1977, and, one by one, the buildings were realised, followed by people gradually moving in. The construction lasted until 1983. During the final phase of construction, the façade-painting design, elaborated in line with urban-technical conditions, was abandoned. It was actually the colouring that was intended to emphasise the complexity and playfulness of Blok's architecture.

The colours were supposed to be used to individualise the buildings, some of their parts and the apartments within the residential complex. However, façade-painting was stopped and cancelled in the aftermath of the campaign, led by fellow-architects, while the final choice was left to the newlyestablished Commission and the Contractor, which eventually "won the battle" of uniformity (Figure 8).

Poor quality of construction in case of some Blok 5 buildings - poor quality of thermal insulation of the facades and improper installation of hydro insulation, the overall imprecision of the construction, poor handling of façade materials - triggered discontent among Users and led to the first illegal "interventions". Last-floor dwellers started to transform the flat roofs into two-vaulted ones, to repair façade insulation of their own accord, in line with their technical abilities and personal preferences, as well as to build over and beyond the existing gauges, which often resulted in completely new housing units.

\footnotetext{
${ }^{34}$ The information in this paragraph has been obtained by the authors, directly from the author of Blok 5.

${ }^{35}$ Built-in closets also served as partitions between the rooms
} 
Figure 8. Blok 5. Facade-painting uniformity (1988-89)

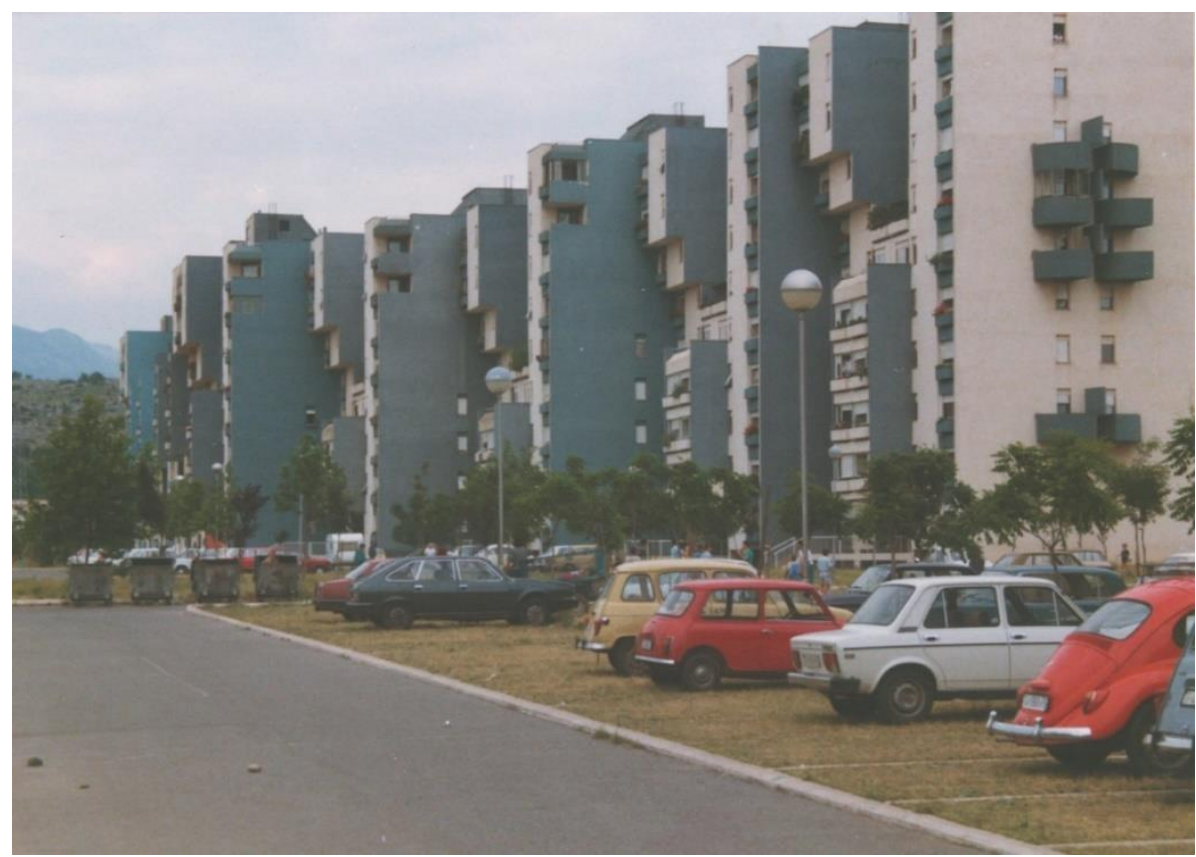

Source: Courtesy of architect Mileta Bojović.

\subsection{Transition-related Interventions of Users and Degradation of Space}

Stojkov (1992, pag. 6) quotes Edmund Bacon's words: "the city reflects with precision the society that has created it, it is like an implacable mirror", that is, in his view, the city speaks volumes about ourselves, about our values and anti-values, our pride and shame, since it represents a physical incarnation of consciousness and an image of the mentality of a certain territory and people inhabiting $i t^{36}$. Given that the physical structure and its image change over history, due to transformations of social relationships and way of thinking, the city embeds in itself layers of intersections, providing for various outcomes in qualitative and communicative sense (Stojkov, 1992). It is exactly these intersections that are clearly visible in Blok 5, which has significantly been changing (although it has not been perfected in use, as Friedman argues) over the forty years of its existence, always reflecting, throughout all those changes, the level of culture and awareness of its users.

First autonomous interventions by dwellers, which were neither supervised by architects, nor guided by regulations, appeared as a reaction to the poor quality of construction of some buildings and were leading to a sort of anarchy and to a slow, yet certain, devastation of the residential complex. These included repairs of facades, transformations of flat roofs into two-vaulted ones, changes in façade outlets...

However, main arbitrary actions that Users were undertaking, that led to complete degradation of architectural buildings within this complex, occurred exactly during the transition period, following the dissolution of SFR Yugoslavia, at the time when the new state institutions-in-the-making had to tackle some more alarming problems than those such as protection of either natural environment, or a built one, in this case.

36 "Ciudad Valiente", chapter of Barcelona En Comú citizen platform, starts with quoting Aristotle: "Barcelona is its citizens" ("Barcelona es su gente") Retrieved from https://barcelonaencomu.cat/es/batalla/ciudad-valiente

ACE, 15 (43) CC BY-ND 3.0 ES | UPC Barcelona, Spain | Self-managing Socialism and its Space: Blok 5 and Challenging 17 Rhetoric of Flexibility. DOI: http://dx.doi.org/10.5821/ace.15.43.9213 


\section{ACE Architecture, City and Environment}

Informal construction in Blok 5 recorded, after 1991, a massive expansion - residents were building several new floors for themselves over the flat roofs and cantilever constructions, building new apartments over the common roof terraces and even constructing the whole houses in the frontgardens of the ground-floor apartments - due to economic and (or) spatial reasons. This uncontrollable state of seizure and misappropriation of (public) space on behalf of the User is not only problematic from the perspective of its visual impact or protection of the author's rights ${ }^{37}$, but also in terms of safety of buildings, having in mind that the 5-meter long cantilevers had been calculated for carrying only their own weight (Figure 9).

Figure 9. Improvement by users or degradation of space: informal construction in Blok 5

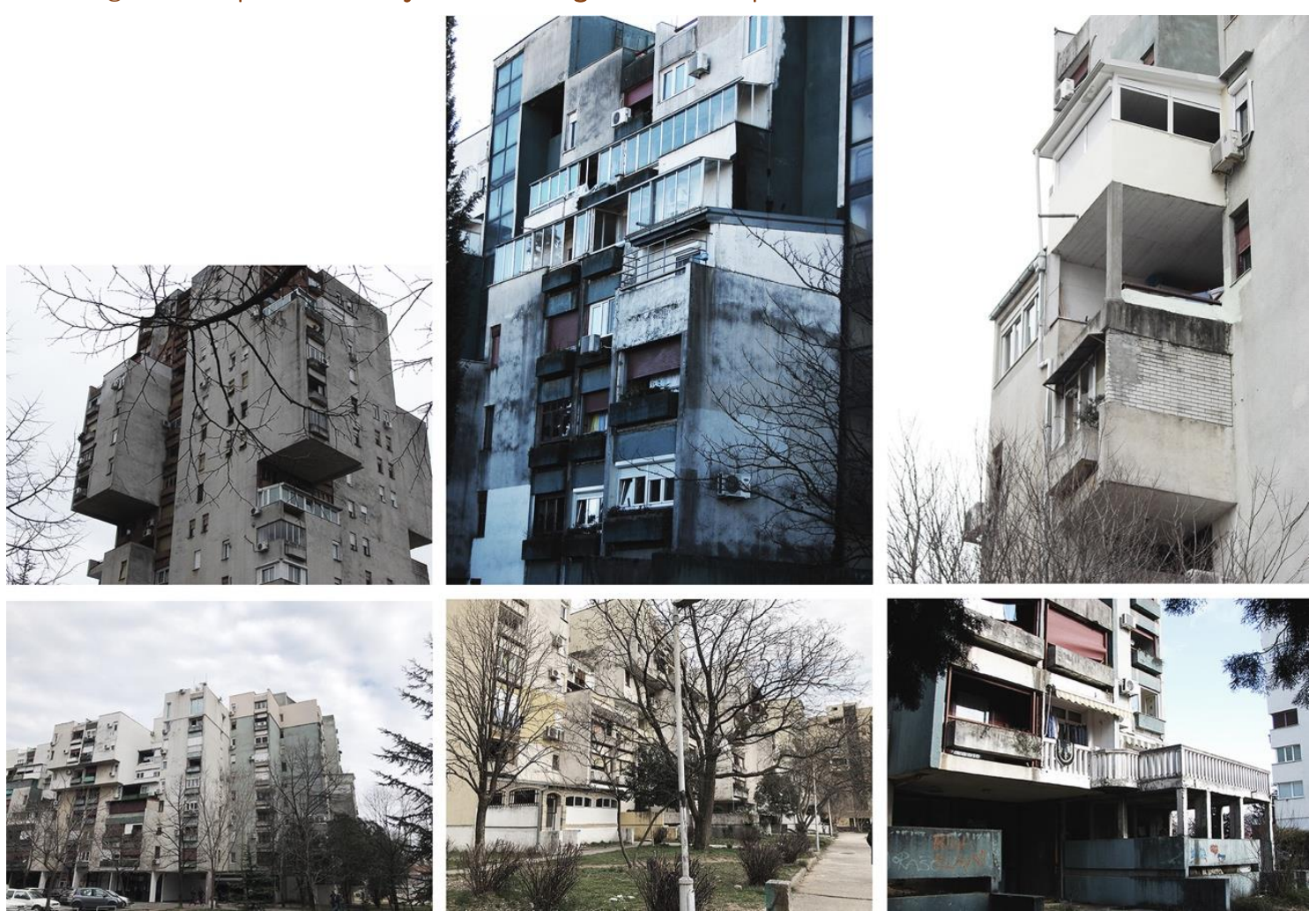

Source: Author's photographs, (2019).

Reasons behind these transformations have been numerous. Nonetheless, their common denominator is the absence of an adequate level of cultural needs in the users of space, that is, a non-existing system of values which would prevent, or, at least, reduce to the smallest possible extent, the negative consequences for the (built) space. The absence of State and its institution favoured additionally the implementation of these devastating interventions.

The concept of residential buildings' flexibility, that is the possibility of major freedom in organising one's own living space degenerated into its very opposite - residents abused of positive sides of the design in an ultimately negative and inappropriate manner, which implied the absence of living culture, followed by breach of regulations. The first and the only attempt to implement the open ${ }^{37}$ The paper mentions the protection of the author's rights, even though the current Law on Copyright and Related Rights
(Official Gazette of MNE 2011, No. 5/05. [in force as of 12/07/2011] does not recognise this category, that is the scope of
protection of the author's rights under this Law covers all other arts, except for architecture (articles 43 and 44 ).

ACE, 15 (43) CC BY-ND 3.0 ES | UPC Barcelona, Spain | Self-managing Socialism and its Space: Blok 5 and Challenging 
building concept in Montenegro did not evoke the expected response among the users, as they were not ready to embrace the possibility of participation in decision-making about their own living space.

\section{In Lieu of Conclusion}

The self-managing socialism, as an advanced social project, which had been seen by urban sociologists and philosophers of the second half of 20th century as a way out of the crisis of capitalist society and the city - was imposed to the Yugoslav society from "top", rather than being the result of needs from "bottom" -that is, from the very society. Therefore, the adoption of the pertaining social norms went slowly, while the society started rather late, almost just before it was about to end, to use the positive sides of the imposed ideology and participate in the decision-making about their own living needs and the very living space.

Therefore, no wonder Blok 5, which had been designed as a flexible, open work, entailing the participatory activity of its users, had all the support of Montenegrin political and state top leadership, whereas it was considerately less accepted by the bottom - primarily by the very profession, and then by its residents.

Did our relatively new experience of living in cities $^{38}$ cost us our possibility to affirmatively use the given advantages of an avant-garde, advanced concept, which was fully in line with contemporary developments in Europe and in the world of that time? Is a longer period of emancipation and raising awareness of citizens about their city and the respective space, what it actually takes in order to treat the space benevolently, while improving it through use?

\subsection{Possible Guidelines for Better Space}

Having in mind all the said thus far, the inevitable conclusion is that it is highly necessary to introduce and implement adequate and effective measures for diminishing negative impacts of society and current socio-economic processes on our cities and on space in total. As the matter is rather complex, it requires simultaneous efforts of all the parties involved - from top to bottom.

Since every society produces its own, personalised space, that space is directly influenced by the level of development of that society. It reflects the responsibility of individuals towards the community, and vice versa, the responsibility of individuals and the society towards their own space and the city, and the relationship of that society and the state towards collective agreement, laws and their enforcement. Blok 5 was used as an example to illustrate all of these interrelations over the timespan of four decades: the architect, promoting participation, in relation with indifferent and non-participative future dwellers and, later, administrative mediators; state top leadership of that time fully supporting the first Montenegrin participatory experience in the field of architecture; degrading activities of dwellers in times of socio-political changes, and these informal and illegal constructions further completely disregarded by the state.

As all the above has been the outcome of a one-dimensional, consumer society together with low level of living culture, the conclusion is that defining the adequate system of values, and qualitative, cultural needs of individuals and society in total, could be the effective tool for diminishing negative impacts on our cities and both natural and built space. In order for this to be achieved, we must

\footnotetext{
38 "Our experience is a provincial one." This is the opening line of the famous work "Philosophy of Province" by Radomir Konstantinović, providing us with an insightful snapshot and a critique of local, Balkan mentality and of the level of cultural emancipation of its society (Konstantinović, 1969, p. 5).
}

ACE, 15 (43) CC BY-ND 3.0 ES | UPC Barcelona, Spain | Self-managing Socialism and its Space: Blok 5 and Challenging

Rhetoric of Flexibility. DOI: http://dx.doi.org/10.5821/ace.15.43.9213 
continuously work on education of all the stakeholders - decision and policy makers, developers, users, and especially architects and urban planners. Architects and urban planners (Puig-Pey, 2017; Galindo González, 2017) both play a very significant part in the whole process and their responsibility should be to continuously educate developers and users about importance and adequate use of our cities and space in general.

Aggravating circumstances are reflected in the fact that today we live in an era of market-driven neoliberal capitalism. The space has lost all its complexity as it has been reduced to goods, assessed by its exchange value and not by its use value. However, space is, beside people, our most valuable resource. Once we acknowledge and accept that space has the highest value only if cultivated, wellmaintained, and further perfected in use, we will begin to make adequate decisions about our cities and natural and built space, in protective and affirmative way, on all levels, even in times of marketdriven economy. This could be of special importance for policy-makers and representatives of the state, in the processes of decision-making regarding our highest common good.

Additionally, we must, as a society, embrace the necessity of active engagement in the matters of our own (living) space and urban everyday life. Participation in decision making, as once argued in the 1960s, is our chance to appropriate space, while strongly identifying with it. However, in order to feel the need or the urge to participate, one has to develop adequate level of awareness and cultural needs first, which brings us back to the importance of continuous education.

In the end, it is an undeniable fact that the quality of citizens influences the quality of their space and the city they live in (Aristotel, 1988), or, in other words, that: "ideal cities must have ideal citizens, it cannot be otherwise - but how to find them and where?” (Bogdanović, 1986, pag. 18) Although the ideal cities and ideal citizens do not exist, we have to strive continuously towards that utopia.

\section{Authorship}

The first author initiated the concept of the research and conducted the theoretical framework, while both authors have worked together on research methodology, investigation and analysis, the resources and visualization of this article.

Conflict of interests: Authors declare no conflict of interest.

\section{Bibliography}

Aristotel. (1988). Politika [Politics]. Zagreb, Hrvatska: Globus.

Barcelona en Comú. Cuidad Valiente. Retrieved from https://barcelonaencomu.cat/es/batalla/ciudadvaliente

Bogdanović, B. (1986). Krug na četiri ćoška [Circle on Four Corners]. Beograd, Srbija: Nolit.

Blagojević, Lj. (2017). French Architectural Departures and its Returns: Belgrade Chic, Balkan Mission, Montenegro Praxis. In Kolešnik, Lj. and Bjažić Klarin, T. (Eds.) French Artistic Culture and Central-East European Modern Art (pp. 144-157). Zagreb, Hrvatska: Institute of Art History.

Bosma, K.; Van Hoogstraten, D. and Vos, M. (2000). Housing for the millions: John Habraken and the SAR (1960-2000). Rotterdam, Belgium: NAI Publishers.

ACE, 15 (4.3) CC BY-ND 3.0 ES | UPC Barcelona, Spain | Self-managing Socialism and its Space: Blok 5 and Challenging 20 Rhetoric of Flexibility. DOI: http://dx.doi.org/10.5821/ace.15.43.9213 
Brusco, L. and Résibois, M. (2018). Lucien Kroll in Cohen, M. (Ed.) Memories Can't Wait. Conversations entre architectes et étudiants (188-217). Bruxelles, Belgium: Éditions de la Faculté d'Architecture La Cambre Horta de l'Université libre de Bruxelles, Clara Architecture/Recherche. DOI: https://doi.org/10.3917/clara.hs5.0188

De Carlo, G. Terni, Nuovo villaggio "Matteotti", Giancarlo De Carlo, 1969-1975, con seguito al 1987. Retrieved from http://architetti.san.beniculturali.it/web/architetti/progetti/schedaprogetti?p p id=56 INSTANCE hlz4\&articleld=14395\&p p lifecycle=1\&p p state=normal\&groupld=10 304\&viewMode=normal

De Jorge-Huertas, V. (2018). Mat-hybrid housing: Two case studies in Terniand London. Frontiers of Architectural Research, 7(3), 276-291. DOI: https://doi.org/10.1016/j.foar.2018.05.002

Doucet, I. (2015). The practice turns in architecture: Brussels after 1968. London, UK: Routledge.

Eco, U. (1962). Opera aperta: Forma e indeterminazione nelle poetiche contemporanee. Milano, Italia: Tascabili Bompiani.

Eco, U. (1989). The Open Work. Cambridge, USA: Harvard University Press.

Erskine, R. (2009). Byker Wall Newcastle-upon-Tyne. In Ebner, P. and Klaffke, J. (Eds), Living Streets Wohnwege (pp. 46-51). Vienna, Austria: Springer.

Felci, L. Villaggio Matteotti. (2003). Retrieved from https://www.docomomoitalia.it/register/MF 37.pdf Friedman, $\quad$ Y. (1958). Spatial city. Retrieved from https://www.moma.org/collection/works/800?artist id=8109\&locale=en\&page=1\&sov referrer=artist

Friedman, Y. (1956). Manifesto de l'Architectura Mobile. Retrieved from http://www.yonafriedman.nl/?page id=225

Friedman, Y. Ville Spatiale. Retrieved from http://www.yonafriedman.nl/?page id=78

Galindo González, J. (2017). ¿Qué urbanismo, para la formación de qué arquitecto? ACE: Architecture, City and Environment, 12 (34): 259-270. DOI: http://dx.doi.org/10.5821/ace.12.34.5292

González Romero, Daniel and Pérez Bourzac, M. T. (2018). La ciudad simultánea: introducción al surglobal. ACE: Architecture, City and Environment, 13 (37), 269-280. DOI: http://dx.doi.org/10.5821/ace.13.37.5564

Guanyem Barcelona. Why do we want to win back Barcelona? Principles and commitments to guide the way. Retrieved from https://guanyembarcelona.cat/wp-content/uploads/2014/06/priciples.pdf

Habraken, N.J. (1988). The Uses of Levels. Keynote Address UNESCO Regional Seminar on Shelter for the Homeless Seoul. Volume 27, No. 2. Gateshead, UK: Open House International. Retrieved from https://www.habraken.com/html/downloads/the_uses_of_levels.pdf

Habraken, N.J. (1972). Supports: an alternative to mass housing. London, UK: Architectural Press.

Heler, A. (1981). Vrednosti i potrebe [The Theory of Need in Marx]. Beograd, Srbija: Nolit.

Ivanović, Z. (1974). Urbano - geografske promjene u razvitku Titograda [Urban-geographical changes during the Development of Titograd]. Titograd, Crna Gora: Skupština opštine Titograd - Odjeljenje za

ACE, 15 (4.3) CC BY-ND 3.0 ES | UPC Barcelona, Spain | Self-managing Socialism and its Space: Blok 5 and Challenging 21 Rhetoric of Flexibility. DOI: http://dx.doi.org/10.5821/ace.15.43.9213 
komunalne poslove i urbanizam [Assembly of Municipality of Titograd - Section for communal utilities and urbanism].

Kalezić, D. (ed.) (1967). Titograd. Zagreb, Hrvatska: Epoha.

Kardelj, E. (1949). O narodnoj demokratiji u Jugoslaviji: povodom novog Zakona o narodnim odborima [About national democracy in Yugoslavia: due to the new Law on people's committees]. Beograd, Srbija: Kultura.

Kendall, S.H. and Teicher, J. (2000). Residential Open Building. New York, USA: E \& FN Spon.

Kirn, G. (2010). Post-fordism and its discontents. Maastricht, Netherlands: Jan van Eyck Academie.

Konstantinović, R. (1969). Filosofija palanke [Provincial Philosophy]. Beograd, Srbija: Otkrovenje.

Kopp, A. (1975). Changer la vie, changer la ville. Paris, France: U.G.E.

Lefebvre, H. (1968). Le droit à la ville. Paris, France: Éditions Anthropos.

Lefebvre, H. (1974). Le production de l'espace. Paris, France: Éditions Anthropos.

Lefebvre, H. (1988). Kritika svakidašnjeg života [Critique of Everyday Life]. Zagreb, Hrvatska: Naprijed.

Lefebvre, H. (1991). The Production of Space. Cambridge, UK: Blackwell.

Maksimović, B. (1980). Urbanizam. Teorija prostornog planiranja i uređenja naselja [Theory of Space Planning and Arrangement of Settlements]. Beograd, Srbija: Naučna knjiga.

Mandić, S. (1992). Reformism in Yugoslavia - Introductory Remarks. In Turner, B.; Hegedus, J. and Tosics, I. (Eds), The Reform of Housing in Eastern Europe and the Soviet Union (pp. 235-244). London, UK: Routledge.

Marcuse, H. (1968). Čovjek jedne dimenzije [One-Dimensional Man]. Sarajevo, Bosna i Hercegovina: Veselin Masleša.

Marković, J. Đ. (1971). Gradovi Jugoslavije [The Cities of Yugoslavia]. Beograd, Srbija: BIGZ.

Milovanović, V. (2016). Alternativne umetničke i kulturalne prakse: slučaj poznosocijalističke Jugoslavije [Alternative Artistic and Cultural Practices: The Case of Late Socialist Yugoslavia] (doctoral dissertation). Univerzitet umetnosti u Beogradu, Beograd.

Milošević, Lj. (1975). Samoupravna interesna zajednica u stambenoj oblasti i stambeni odnos [SelfManaging Communities of Interest in the Housing Sector and Housing Relations]. In Zbornik 9 Supp (p. 59). Retrieved from https://heinonline.org/HOL/LandingPage?handle=hein.journals/zborrado10\&div=9\&id=\&page=

Minton, A. (May 21 th 2015$)$. Byker Wall: Newcastle's noble failure of an estate - a history of cities in 50 buildings, day 41. The Guardian. Retrieved from https://www.theguardian.com/cities/2015/may/21/byker-wall-newcastles-noble-failure-of-anestate-a-history-of-cities-in-50-buildings-day-41

Mumford, L. (1988). Grad u historiji [The City in History]. Zagreb, Hrvatska: Naprijed.

Open building. Manifesto. Retrieved from https://www.openbuilding.co/manifesto

ACE, 15 (43) CC BY-ND 3.0 ES | UPC Barcelona, Spain | Self-managing Socialism and its Space: Blok 5 and Challenging 22 Rhetoric of Flexibility. DOI: http://dx.doi.org/10.5821/ace.15.43.9213 
Pavić, M. (1984). Hazarski rečnik [Dictionary of the Khazars]. Beograd, Srbija: Prosveta.

Pendlebury, J., Townshend, T., and Gilroy, R. (2009). Social housing as heritage: The case of Byker, Newcastle upon Tyne. In Gibson, L. \& Pendlebury, J. (Eds.), Valuing historic environments (pp. 179200). Farnham, UK: Ashgate.

Petranović, B. (1988). Istorija Jugoslavije 1918-1988: Socijalistička Jugoslavija 1945-1988. book 3 [The history of Yugoslavia 1918-1988: Socialist Yugoslavia 1945-1988] (pp. 120-160). Beograd, Srbija: Nolit.

Puig-Pey, A. (2017). El arquitecto: formación, competencias y práctica profesional. ACE: Architecture, City and Environment, 12 (34), 301-320. DOI: http://dx.doi.org/10.5821/ace.12.34.5296

Republički zavod za urbanizam i projektovanje. (1978). Dispoziciono rješenje - šeme prodaje sa tipologijom stanovanja, Blok 5 - zgrada D2. Titograd, Crna Gora: SIZ stanovanja Titograd. [Republic Bureau for Urbanism and Architecture. (1978). Apartment typology, Blok 5 - building D2. Titograd, Montenegro: SIZ housing, Titograd].

Republički zavod za urbanizam i projektovanje. (1973). Generalni urbanistički plan Titograda GUP 1973. Titograd, Crna Gora: Skupština opštine Titograd. [Republic Bureau for Urbanism and Architecture. (1973). General Urban Plan of Titograd. Montenegro: Assembly of the Municipality of Titograd].

Schlimme, H. (2009). The Mediterranean Hill Town: A Travel Paradigm. In Traganou, J. and Mitrašinović, M. (Eds), Travel, Space, Architecture (pp. 148-166). New York, USA: Routledge.

Spatial agency. Participation. Movement - $\quad$ Europe. Retrieved from https://www.spatialagency.net/database/why/political/participation.1970s

Statistical office of Montenegro. (2011). Census of Population, Households and Dwellings in Montenegro. Podgorica, Crna Gora: Statistical Office of Montenegro.

Stojkov, B. (1992). Plan i sudbina grada [The Plan and the Destiny of the City]. Beograd, Srbija: Građevinska knjiga.

Supek, R. (1987). Grad po mjeri čovjeka [A City Tailored to Human]. Zagreb, Hrvatska: Naprijed.

Tschumi, B. (2004). Arhitektura i disjunkcija [Architecture and Disjunction]. Zagreb, Hrvatska: AGM.

Urbanisticki institut SR Slovenije. (1989). Prostorni plan opštine Titograd, Revizija Generalnog urbanističkog plana Titograda GUP 1989. Titograd, Crna Gora: Skupština opštine Titograd. [Urban Institute of SR SLOVENIA. (1989). Spatial Plan of the Municipality of Titograd, Revision of the General Urban Plan of Titograd GUP 1989. Titograd, Montenegro: Assembly of the Municipality of Titograd.].

Walters, D. and Brown, L. L. (2004). Design First: Design-based Planning for Communities. Oxford, UK: Architectural Press.

Zavod za urbanizam. (1964). Generalni urbanistički plan grada Titograda. Titograd, Crna Gora: Skupština opštine Titograd. [Institute of Urbanism. (1964). General urban plan of the city of Titograd. Titograd, Montenegro: Assembly of the Municipality of Titograd.].

Zukin, S. (1975). Beyond Marx and Tito: Theory and Practice of Yugoslav Socialism. Cambridge, UK: Cambridge University Press. 